Research Article

\title{
Motivation Scale for STEM Fields
}

\author{
Esra KIZILAY*1(D), Havva YAMAK 2(D) Nusret KAVAK ${ }^{3}$ (D) \\ ${ }^{1}$ Erciyes University, Kayseri, Turkey, eguven@erciyes.edu.tr \\ ${ }^{2}$ Gazi University, Faculty of Education, Ankara, Turkey, havva@gazi.edu.tr \\ ${ }^{3}$ Gazi University, Faculty of Education, Ankara, Turkey, nkavak@gazi.edu.tr \\ * Corresponding Author: eguven@erciyes.edu.tr
}

\begin{tabular}{|c|c|}
\hline Article Info & Abstract \\
\hline $\begin{array}{l}\text { Received: } 9 \text { September } 2019 \\
\text { Accepted: } 10 \text { October } 2019 \\
\text { Keywords: STEM motivation, STEM } \\
\text { career, scale development } \\
\text { DOI: 10.18009/jcer.617514 } \\
\text { Publication Language: English }\end{array}$ & $\begin{array}{l}\text { In this study, it is aimed to develop a measurement tool to be used to } \\
\text { determine the motivation of high school students towards STEM fields. } \\
29 \text {-item motivation scale trial form for STEM fields was applied to } 462 \\
\text { high school students in their 2016-2017 academic years, studying in } \\
\text { four schools of Kayseri. Exploratory Factor Analysis (EFA) and } \\
\text { Confirmatory Factor Analysis (CFA) was performed for the construct } \\
\text { validity through the data set obtained from the study group. According } \\
\text { to the results of Exploratory Factor Analysis (EFA), it was determined } \\
\text { that the scale consisted of } 22 \text { items and } 4 \text { sub-dimensions. Scale } \\
\text { subdimensions were named as: confidence, relevance, attention, } \\
\text { satisfaction. It was determined that the four-factor structure related to } \\
\text { the scale explained } 78 \% \text { of the total variance. The Cronbach alpha } \\
\text { coefficient was } 97 \text { for the whole scale. }\end{array}$ \\
\hline open 1 access $\bigcirc$ CrossMark & $\begin{array}{l}\text { To cite this article: Kızılay, E., Yamak, H., \& Kavak, N. (2019). } \\
\text { Motivation scale for STEM fields. Journal of Computer and Education } \\
\text { Research, } 7 \text { (14), 540-557. DOI: } 10.18009 / \text { jcer. } 617514\end{array}$ \\
\hline
\end{tabular}

\section{Introduction}

Today, we are living the "industry 4.0 " revolution, which was first mentioned in 2011, symbolizing digital industrial technology. "Industry 4.0" is a transformation process. This transformation leads to the production of high-quality products at low cost, faster and more efficient production, thereby an increase in productivity, changes in the economy and labor profile, a reshape in the competitiveness of countries (BCG, 2019; Kuscu, 2018). Therefore, in order to compete in today's competitive environment, each country should give importance to "industry 4.0 " technologies.

"Industry 4.0" includes technologies such as autonomous robots, simulation, system integrations, industrial internet of objects, cyber security, cloud, additive manufacturing, augmented reality, big data and analytics (BCG, 2019). When we look at these technologies, they are fundamentally related to STEM (science, technology, engineering and mathematics) fields. Regarding the STEM professions in the 2015 report of the UK Commission for 
Employment and Skills (UKCES), it can be seen that they include the occupations involving "industry 4.0" technologies such as programmers and software development experts, airplane pilots and flight engineers, web design and development experts, design and development engineers, information technology and telecommunications managers (UKCES, 2015). Therefore, countries should give importance to STEM fields and labor force in these fields in addition to "industry 4.0 " technologies. Within this framework, many countries have started to carry out works on STEM education and STEM careers. The data contained in a report on STEM education including the information about 30 countries, supports this conclusion. The report states that approximately $80 \%$ of the countries currently define STEM education as a priority field at national level (Kearney, 2016). The target of most countries is to increase labor force in STEM fields. In order to increase the rate of employment in STEM fields, students should be interested in these fields, prefer these fields in their career path and first of all, they should have high motivation towards STEM fields. Because motivation is one of the variables that highly affect students' career choice and career interest (Wang, 2013; Christensen, Knezek \& Tyler-Wood, 2015; Bahar \&Adiguzel, 2016; Aeschlimann, Herzog \& Makarova, 2016). In this context, the motivation of students towards STEM fields is gaining importance. However, the review of related literature revealed that there are limited number of motivation studies related to STEM fields. In addition, a scale related to STEM motivation was not found in the literature.

The articles related to STEM education between 1999 and 2013 were evaluated in a study reviewing the related literature and it was found that there are few studies related to motivation (Jayarajah, Saat \& Rauf, 2014). In another study examining STEM education works performed between 2013 and 2015, no study related to motivation was observed (Mizell and Brown, 2016).

Regarding the researches related to STEM and motivation in the literature, it was concluded in a study that science motivation predicted STEM career interest of high school students (Robnett \& Leaper, 2012). In another study, it was found that self-motivation is among the factors affecting STEM careers and STEM interest of high school students included in an academy (Christensen, Knezek \& Tyler-Wood, 2015). A similar result was revealed in a study conducted by Bahar and Adiguzel (2016). In the study, it was found that the most important factor affecting American High School students' career in STEM related fields was self-motivation. 
It was found that there are many STEM studies related to scale development in literature. Tyler-Wood, Knezek and Christensen (2010) developed two scales that can be used to evaluate STEM disciplines and career perceptions. Kier et al. (2013) developed a scale about STEM career interest. Oh et al. (2013) developed a measurement tool that measures the STEM career interests of high school students. Guzey, Harwell and Moore (2014) developed a tool to measure the attitudes of students (grades 4-6) towards STEM and STEM careers. Milner, Horan and Tracey (2014) developed measurement tools that could be used to determine STEM interests and self-efficacy of students. In the study conducted by Buyruk and Korkmaz (2016), a scale that can be used to determine STEM awareness of prospective teachers was developed. In their research, Haciomeroglu and Bulut (2016) adapted a scale related to orientation to STEM teaching in Turkish. Koyunlu Unlu et al. (2016) adapted the career interest scale to Turkish for the sample of secondary school students. Derin, Aydin and Kirkic (2017) developed a scale that measures the attitudes of adults to STEM education. A scale to determine STEM awareness of secondary school teachers was developed by Cevik (2017). Yilmaz et al. (2017), an attitude scale related to STEM education was adapted to Turkish. Yildirim and Selvi (2015) adapted a STEM attitude scale to Turkish.

When all these studies are examined, it is seen that there is no scale related to STEM motivation. Regarding the researches related to STEM motivation, it was found that motivation was generally addressed along with career and interest and not investigated as a separate variable. In this context, the research was conducted in accordance with the need in the relevant literature. Therefore, it is believed that the research will contribute to the literature.

Purpose of the Study

In this research, it was aimed to develop a scale that can be used to measure the motivation of high school students towards STEM fields.

\section{Method}

Working Group

The scale was administered to 462 students from four high schools in Kayseri in Turkey, at the beginning of the second semester of 2016-2017 academic year. Information about the students is given in Table 1. 
Table 1. Distribution of students according to schools and gender

\begin{tabular}{|c|c|c|c|c|c|}
\hline School Type & Schools & Grade & Male & Female & Total \\
\hline \multirow{5}{*}{ Anatolian Imam Hatip High Schools } & School 1 & 9 & 43 & 7 & 50 \\
\hline & & 10 & 28 & 22 & 50 \\
\hline & & 11 & 17 & - & 17 \\
\hline & & 12 & 21 & 19 & 40 \\
\hline & & Total & 109 & 48 & 157 \\
\hline \multicolumn{3}{|c|}{ Anatolian Imam Hatip High Schools Total } & 109 & 48 & 157 \\
\hline \multirow{5}{*}{$\begin{array}{l}\text { Vocational and Technical Anatolian High } \\
\text { Schools }\end{array}$} & School 2 & 9 & 8 & - & 8 \\
\hline & & 10 & 8 & 2 & 10 \\
\hline & & 11 & 5 & 3 & 8 \\
\hline & & 12 & 5 & 3 & 8 \\
\hline & & Total & 26 & 8 & 34 \\
\hline \multicolumn{3}{|c|}{ Vocational and Technical Anatolian High Schools Total } & 26 & 8 & 34 \\
\hline \multirow[t]{10}{*}{ Anatolian High Schools } & School 3 & 9 & 16 & 19 & 35 \\
\hline & & 10 & 16 & 24 & 40 \\
\hline & & 11 & 10 & 10 & 20 \\
\hline & & 12 & 10 & 8 & 18 \\
\hline & & Total & 52 & 61 & 113 \\
\hline & School 4 & 9 & 18 & 22 & 40 \\
\hline & & 10 & 13 & 27 & 40 \\
\hline & & 11 & 19 & 39 & 58 \\
\hline & & 12 & 9 & 11 & 20 \\
\hline & & Total & 59 & 99 & 158 \\
\hline \multicolumn{3}{|l|}{ Anatolian High Schools Total } & 111 & 160 & 271 \\
\hline \multicolumn{3}{|l|}{ Overall Total } & 246 & 216 & 462 \\
\hline
\end{tabular}

Validity and reliability studies of the scale were carried out on the basis of student data given in Table 1.

\section{Application}

In this research, the Motivation Scale for STEM Fields was developed for high school students. The scale development principles specified by DeVellis (2014) were taken into consideration during the development of the scale (Figure 1).

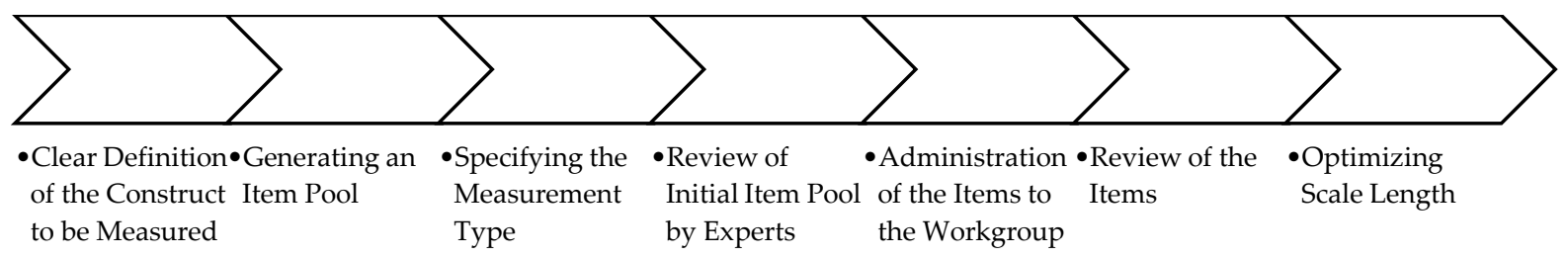

Figure 1. Scale development principles [Shaped according to the scale development principles specified by DeVellis (2014)]. 
Clear Definition of the Construct to be Measured

A scale should be based on important theories about the fact to be measured. Therefore, while developing the scale, the structural characteristics (subdimension/factor/component) of the fact to be analyzed are determined by reviewing the relevant field literature (DeVellis, 2014; Ozdamar, 2016). In this study, during the development of Motivation Scale for STEM Fields, similar scales and the theories and various studies on which these scales have been based were reviewed. As a result of the analyzes, it was decided to take ARCS Model as the base of the scale (Keller, 1984; cited in Keller, 2010). The reasons for this choice are; it is a higher-level model also explaining other theories, it is based on an extensive review of motivational literature, the categories explained by other theories are inadequate in practice, and other theories are inadequate outside of the field they explain (Keller, 2010).

The ARCS Model is described in four categories, which are attention, relevance, confidence and satisfaction (Keller, 2010). In the study, these four categories were determined as sub-dimensions while developing the Motivation Scale for STEM Fields.

\section{Generating an Item Pool}

When developing a scale, the item pool should be as large as possible and each item should be prepared to reflect the relevant construct (DeVellis, 2014). In this research, a pool of 33 items was prepared.

\section{Specifying the Measurement Type}

Likert type scaling was used in this research. Likert scales contain response options that indicate the level of agreement or approval to the sentence given as an item (DeVellis, 2014). In this research, the scale is of Likert type because the motivation scale attempt to determine students' level of agreement to the given items.

\section{Review of Initial Item Pool by Experts}

An expert evaluation form was prepared for the evaluation of the 33-item pool. Based on feedback from experts in STEM training, motivation and assessment, each item was reexamined and corrected and a scale containing 29 positive items was prepared. Examples of items in the item pool and resources used in writing items are given in Table 2. Some items 
were prepared according to the opinions of researchers and experts. Sources used in item preparation were; Cetin Dindar and Geban (2015), Keller (2010), Tahiroglu and Cakır (2014).

Review of the Items and Giving the Appropriate Form

While scoring the items in the scale, the respondents were asked to give a score between 1-5 to each item, by filling the blanks with science, technology, engineering and mathematics respectively. Then, the scores that students gave separately for science, technology, engineering and mathematics fields were summed and divided into four for each item. In this way, the item score of each item was formed. Therefore, item scores varied between 1 and 5. The items were analyzed after calculating students' scores for each item.

Table 2. Examples of items in the item pool and resources used in writing items

\begin{tabular}{|c|c|c|c|c|c|c|c|}
\hline No & Items & $\begin{array}{l}\mathscr{U} \\
\mathscr{E} \\
\mathscr{D} \\
\mathscr{D}\end{array}$ & 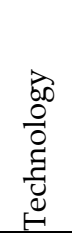 & 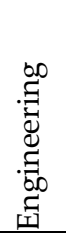 & 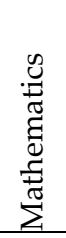 & 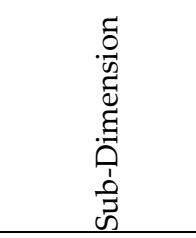 & 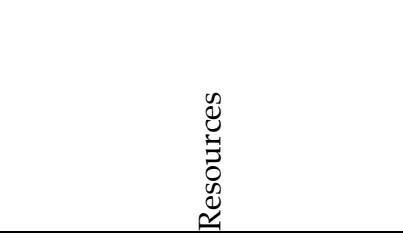 \\
\hline 1 & $\begin{array}{l}\text { There are interesting events in the } \\
\text { field of .... }\end{array}$ & & & & & \multirow{8}{*}{ Attention } & \\
\hline 2 & & & & & & & \\
\hline 3 & & & & & & & Keller, 2010 \\
\hline 4 & & & & & & & Keller, 2010 \\
\hline 5 & & & & & & & $\begin{array}{l}\text { Çetin Dindar and Geban, } \\
2015\end{array}$ \\
\hline 6 & & & & & & & Keller, 2010 \\
\hline 7 & & & & & & & Keller, 2010 \\
\hline 8 & & & & & & & \\
\hline 9 & $\begin{array}{l}\text { I can make a connection between } \\
\text { daily life and ... field. }\end{array}$ & & & & & \multirow{8}{*}{ Relevance } & Keller, 2010 \\
\hline 10 & & & & & & & Keller, 2010 \\
\hline 11 & & & & & & & Keller, 2010 \\
\hline 12 & & & & & & & \\
\hline 13 & & & & & & & Keller, 2010 \\
\hline 14 & & & & & & & \\
\hline 15 & & & & & & & \\
\hline 16 & & & & & & & $\begin{array}{l}\text { Çetin Dindar and Geban, } \\
\text { 2015; Keller, } 2010\end{array}$ \\
\hline 17 & & & & & & \multirow{6}{*}{ Confidence } & $\begin{array}{l}\text { Çetin Dindar and Geban, } \\
2015\end{array}$ \\
\hline 18 & $\begin{array}{l}\text { I am sure that I will understand the } \\
\text { topics in the field of ... }\end{array}$ & & & & & & $\begin{array}{l}\text { Çetin Dindar and Geban, } \\
\text { 2015; Keller, } 2010\end{array}$ \\
\hline 19 & & & & & & & $\begin{array}{l}\text { Keller, 2010; Tahiroğlu and } \\
\text { Çakır, 2014 }\end{array}$ \\
\hline 20 & & & & & & & $\begin{array}{l}\text { Çetin Dindar and Geban, } \\
\text { 2015; Keller, } 2010\end{array}$ \\
\hline 21 & & & & & & & \\
\hline 22 & & & & & & & Çetin Dindar and Geban, \\
\hline
\end{tabular}




\begin{tabular}{|c|c|c|c|}
\hline & & \multicolumn{2}{|r|}{2015} \\
\hline \multicolumn{3}{|c|}{23} & \\
\hline 24 & & & $\begin{array}{l}\text { Çetin Dindar and Geban, } \\
\text { 2015; Keller, } 2010\end{array}$ \\
\hline 25 & & & $\begin{array}{l}\text { Çetin Dindar and Geban, } \\
2015\end{array}$ \\
\hline & I enjoy topics in ... field & & $\begin{array}{l}\text { Çetin Dindar ve Geban, } \\
\text { 2015; Keller, } 2010\end{array}$ \\
\hline \multicolumn{3}{|c|}{27} & \\
\hline \multicolumn{3}{|c|}{28} & \\
\hline 29 & & & \\
\hline
\end{tabular}

The validity and reliability studies of the items and the final version of the scale are discussed in the findings section. While preparing the items, the word STEM was not used, and the scores were marked in separate columns for the disciplines (science, technology, engineering and mathematics). The reasons underlaying it; lack of definition of STEM department in higher education in Turkey, the word STEM is not meaningful for the students in Turkey and such a correction was proposed in expert opinions.

\section{Data Analysis}

Following the administration of the Motivation Scale for STEM Fields to the workgroup, exploratory factor analysis was performed, and the scale was finalized. Confirmatory factor analysis, reliability analysis was performed on the final form of the scale; item variances, item mean scores, corrected item total correlations, difference between lower and upper groups of $27 \%$ were calculated. SPSS 22 and AMOS 24 software were used in the analysis of the data.

\section{Findings}

\section{Exploratory Factor Analysis}

$\mathrm{KMO}$ value of the scale was found to be 0.973 and Bartlett's test was found to be significant $(p<.05)$. According to the results obtained from the KMO and Bartlett's tests of the scale's item pool, it was decided to continue the factor analysis.

In the study, the limit value for factor load was set as 0.30 . There was no item with a factor load below 0.30. Article 28 was removed from the scale because of overlapping.

After removing the item, varimax, one of the vertical rotation techniques, was used. Following the application of this technique, "rotated component matrix" table was checked, the overlapping items 7, 8 and 26 were removed from the scale and factor analysis was repeated using "varimax" technique. As a result of the analysis, it was found that all items 
except items 9, 14 and 16 were distributed according to theoretical background. After reviewing these items, it was decided to remove them from the scale.

Factor analysis was performed again on the 22-item scale after removing mentioned items, using "varimax" technique. The total variance table explained as a result of factor analysis is given in Table 3. According to Table 3, the scale consisted of four factors explaining $78 \%$ of the analyzed construct. "Scree Plot" graph of the scale is given in Figure 2.

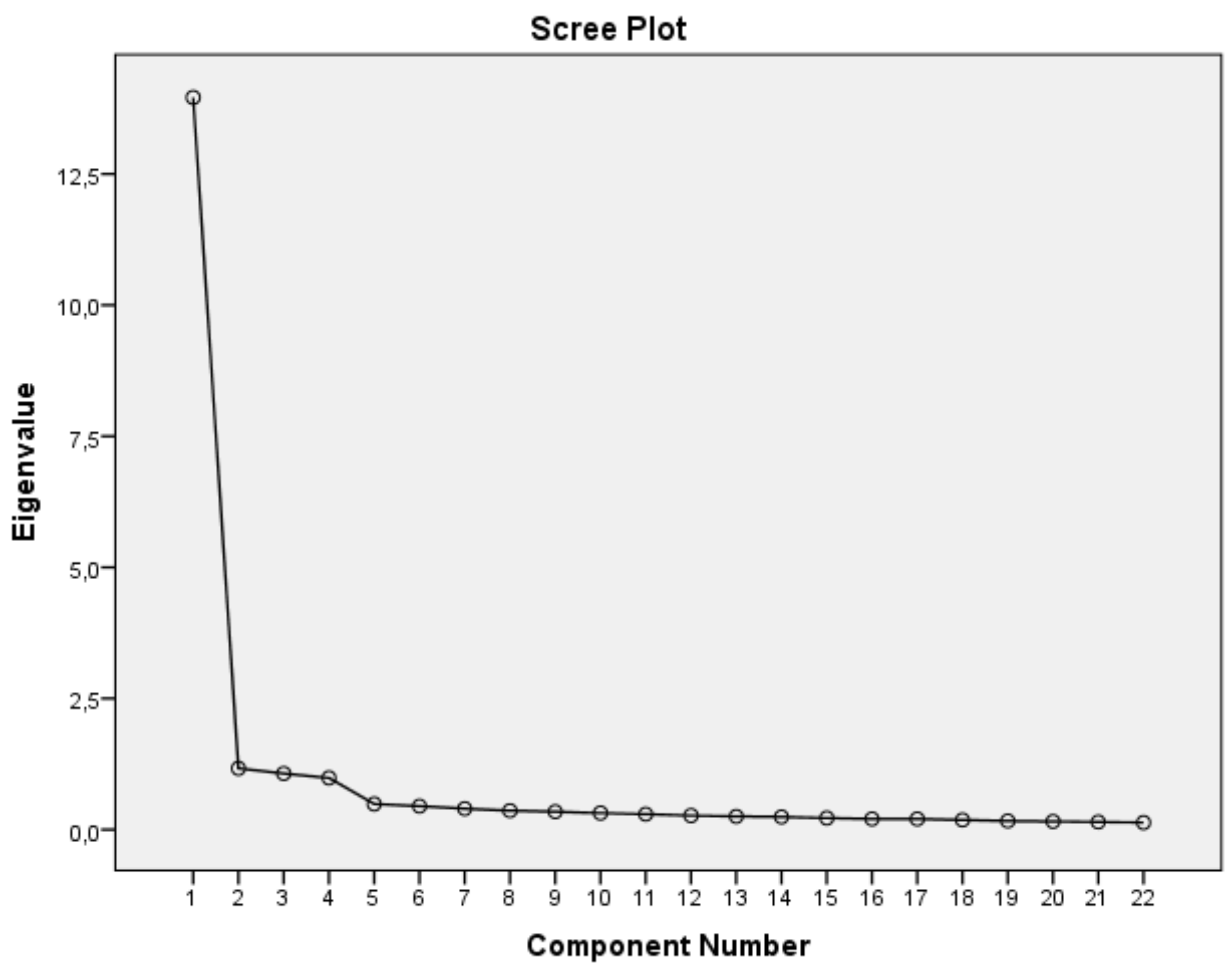

Figure 2. "Scree Plot" graph of Motivation scale for STEM fields

Table 3. Motivation scale for STEM fields - Total Variance Table

\begin{tabular}{llll}
\hline \multirow{2}{*}{ Components } & \multicolumn{3}{l}{ Initial Eigenvalues } \\
\cline { 2 - 4 } Total & Variance Percentage & Cumulative Percentage \\
\hline 1 & 13.959 & 63.452 & 63.452 \\
2 & 1.167 & 5.304 & 68.756 \\
3 & 1.070 & 4.863 & 73.618 \\
4 & .985 & 4.479 & 78.098 \\
\hline 5 & .488 & 2.219 & 80.317 \\
6 & .447 & 2.033 & 82.350 \\
7 & .401 & 1.821 & 84.171 \\
8 & .361 & 1.640 & 85.812 \\
9 & .341 & 1.549 & 87.360 \\
10 & .315 & 1.432 & 88.792 \\
11 & .294 & 1.335 & 90.127 \\
12 & .267 & 1.215 & 91.342 \\
13 & .252 & 1.143 & 92.485 \\
14 & .243 & 1.103 & 93.588 \\
15 & .220 & 1.000 & 94.589
\end{tabular}




\begin{tabular}{llll}
16 & .205 & .931 & 95.519 \\
17 & .203 & .922 & 96.442 \\
18 & .183 & .833 & 97.275 \\
19 & .164 & .745 & 98.020 \\
20 & .156 & .710 & 98.730 \\
21 & .146 & .662 & 99.392 \\
22 & .134 & .608 & 100.000 \\
\hline
\end{tabular}

Regarding Figure 2, the number of factors was found to be four.

In order to determine the sub-dimensions of the items, "rotated component matrix" table was used. The distribution of the scale items in four sub-dimensions is given in Table 4 . Regarding the table, it is seen that the scale consists of four sub-dimensions/factors, the factors don't have overlapping items and the load value of each item within the factor is higher than 0.30. According to these results, the scale consists of 22 items, under four factors.

The factors in the scale and the items are given below with their factor names.

Factor 1: Confidence sub-dimension; item 17, 18, 19, 20, 21, 22

Factor 2: Relevance sub-dimension; item 10, 11, 12, 13, 15

Factor 3: Attention sub-dimension; item 1, 2, 3, 4, 5, 6

Factor 4: Satisfaction sub-dimension; item 23, 24, 25, 27, 29

Table 4. Motivation scale for STEM fields - Rotated Component Matrix

\begin{tabular}{|c|c|c|c|c|}
\hline \multirow{2}{*}{ Items } & \multicolumn{4}{|c|}{ Factors } \\
\hline & 1 & 2 & 3 & 4 \\
\hline mot18 & .770 & & & \\
\hline $\operatorname{mot} 19$ & .739 & & & \\
\hline $\operatorname{mot} 20$ & .736 & & & \\
\hline $\operatorname{mot} 22$ & .721 & & & \\
\hline $\operatorname{mot} 21$ & 693 & & & \\
\hline $\operatorname{mot} 17$ & .661 & & & \\
\hline mot12 & & .764 & & \\
\hline $\operatorname{mot} 11$ & & .755 & & \\
\hline $\operatorname{mot} 13$ & & .747 & & \\
\hline $\operatorname{mot} 15$ & & .713 & & \\
\hline $\operatorname{mot} 10$ & & .701 & & \\
\hline mot1 & & & .763 & \\
\hline mot5 & & & .715 & \\
\hline mot2 & & & .705 & \\
\hline mot3 & & & .701 & \\
\hline $\operatorname{mot} 4$ & & & .664 & \\
\hline$\underline{\operatorname{mot} 6}$ & & & .657 & \\
\hline $\operatorname{mot} 27$ & & & & .780 \\
\hline $\operatorname{mot} 29$ & & & & .774 \\
\hline $\operatorname{mot} 24$ & & & & .757 \\
\hline
\end{tabular}




\section{Confirmatory Factor Analysis}

In the confirmatory factor analysis, $\chi^{2} /$ sd value was found to be 3.293 , CFI value was calculated as 953. RMSEA value was found to be 071. Based on these results, it can be said that the scale construct that is obtained by exploratory factor analysis is validated and it is acceptable in terms of fit indices.

The standardized regression values, i.e. factor loads, obtained from the confirmatory factor analysis are given in Figure 3.

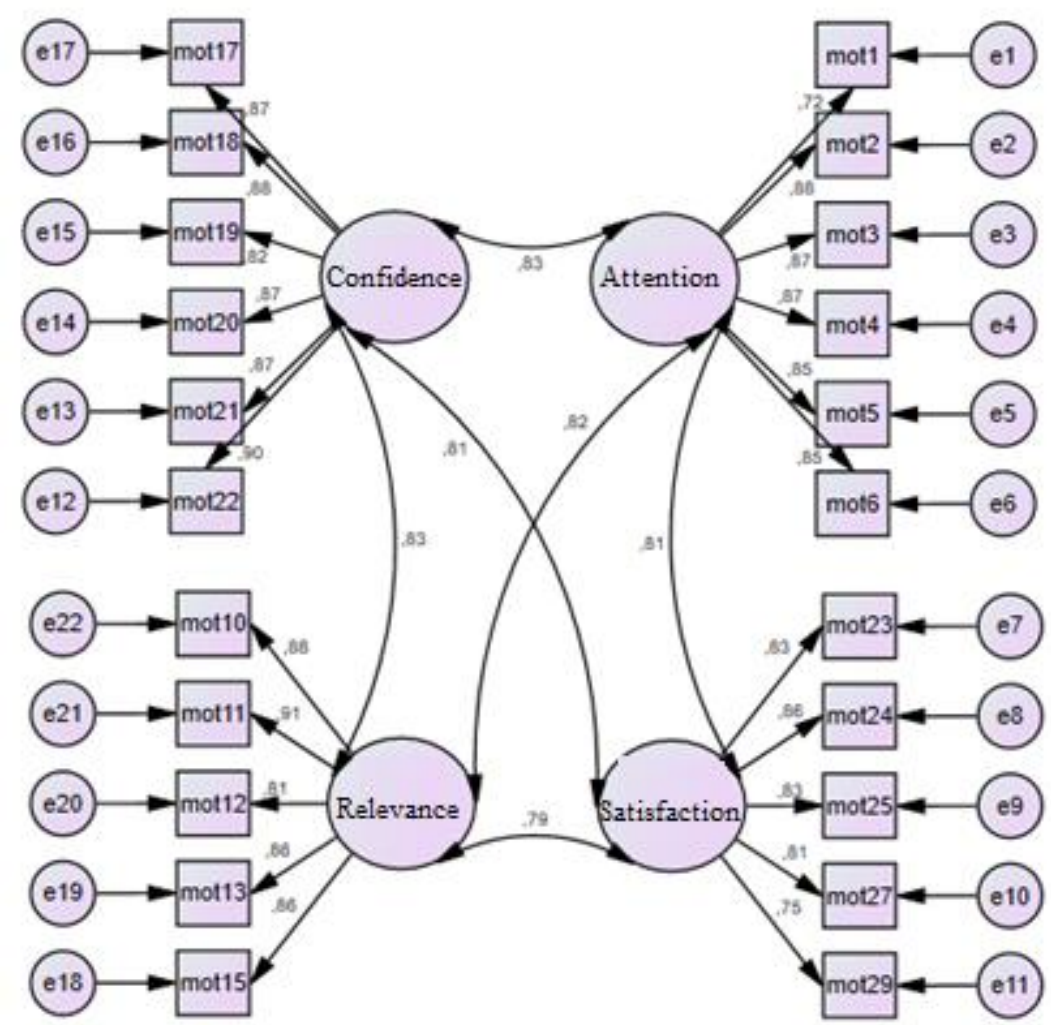

Figure 3. Motivation scale for STEM fields - Path Diagram

Regarding the factor loads of the scale, they ranged between $0.82-0.90$ for confidence sub-dimension; $0.72-0.88$ for attention sub-dimension; $0.81-0.91$ for relevance sub-dimension; and $0.75-0.86$ for satisfaction sub-dimension. Since $p<.05$ for these values, the items were appropriately assigned to the factors. 
In addition to these results, covariance, correlation and variance values among subdimensions are also important. According to the results, the following strong relationships were revealed between the factors: confidence \& attention - load 0.83, confidence \& relevance - load 0.83 , confidence \& satisfaction - load 0.81 , attention \& relevance - load 0.82 , attention \& satisfaction - load 0.81 , relevance \& satisfaction - load 0.79 .

\section{Reliability Analysis}

The Cronbach Alpha coefficients of the whole scale and its sub-dimensions is given in Table 5. According to these results, both the whole scale and its dimensions have high reliability.

Table 5. Cronbach's Alpha Coefficients of the Scale

\begin{tabular}{lcc}
\hline Sub-dimensions & Number of Items & Cronbach Alpha coefficient $(\alpha)$ \\
\hline Confidence & 6 & .95 \\
Relevance & 5 & .94 \\
Attention & 6 & .93 \\
Satisfaction & 5 & .91 \\
Whole scale & 22 & .97 \\
\hline
\end{tabular}

Item Variances

It is important that the items of a scale have high variance. The variances of the items of the Motivation Scale for STEM Fields are given in Table 6.

Table 6. Motivation scale for STEM fields - Item Variances

\begin{tabular}{llll}
\hline Items & Variance Statistics & Items & Variance Statistics \\
\hline mot1 & .859 & $\operatorname{mot} 17$ & .769 \\
$\operatorname{mot} 2$ & .703 & $\operatorname{mot} 18$ & .758 \\
$\operatorname{mot} 3$ & .770 & $\operatorname{mot} 19$ & .895 \\
$\operatorname{mot} 4$ & .820 & $\operatorname{mot} 20$ & .821 \\
$\operatorname{mot} 5$ & .776 & $\operatorname{mot} 21$ & .782 \\
$\operatorname{mot} 6$ & .770 & $\operatorname{mot} 22$ & .820 \\
$\operatorname{mot} 10$ & .900 & $\operatorname{mot} 23$ & .804 \\
$\operatorname{mot} 11$ & .869 & $\operatorname{mot} 24$ & .943 \\
$\operatorname{mot} 12$ & 1.155 & $\operatorname{mot} 25$ & .873 \\
$\operatorname{mot} 13$ & .917 & $\operatorname{mot} 27$ & .890 \\
$\operatorname{mot} 15$ & .877 & $\operatorname{mot29}$ & .977 \\
\hline
\end{tabular}

According to Table 6, the variance statistics for all scale items are higher than 0.703 . 
Item Mean Scores

Since item scores vary from 1 to 5 in the study, another feature desired in the scale is that the mean scores of the items being close to 3. In the study, the mean scores of the scale items ranged from 3.09 to 3.48 .

Item Total Correlations

Items on a scale should have a strong relationship with the item group outside of them. In the study, corrected item total correlation for all items of the scale was greater than 0.640 .

Difference between the Lower and Upper Groups of $27 \%$

T-test results of the scale between the lower and upper groups are given in Table 7.

Table 7. Independent groups t-test results between lower and upper students

\begin{tabular}{lllllll}
\hline Groups & $\mathrm{N}$ & Mean & Ss & $\mathrm{t}$ & $\mathrm{df}$ & $\mathrm{p}$ \\
\hline Lower & 125 & 52.94 & 12.62 & & & \\
$\begin{array}{l}\text { Group } \\
\text { Upper }\end{array}$ & 125 & 90.62 & 7.60 & -28.599 & 203.553 & .000 \\
Group & & & & & & \\
\hline
\end{tabular}

As $\mathrm{p}<.05$, there is a significant difference between the lower and upper groups in terms of overall scale scores. The mean score of the upper group was 90.62, whereas the mean score of the lower group was 52.94. Therefore, it can be said that the scale can measure the distinction between students with low and high scores.

As a result of the factor analyzes, item analyzes and reliability analyzes described above, a valid and reliable 22-item and four-factor Motivation scale for STEM fields was developed (Appendix 1).

\section{Discussion and Conclusions}

In the research, Motivation scale for STEM fields was developed for high school students. When developing the scale, the scale development steps suggested by DeVellis (2014) were followed, which have been also followed in many scales developed in the field of education (Baypinar and Tarim, 2019; Ilhan and Cetin, 2013; Seker and Kaya, 2018). 
Many analyzes were performed to check the validity and reliability of the item pool. First, exploratory factor analysis was applied to the scale. As a result of the analysis, it was found that the scale explained $78 \%$ of the construct and consisted of four factors. Regarding the "Scree Plot" graph of the scale, it was seen that the factors contributed to the variance after the fourth factor were very close to each other. In addition, the slope is flattened after the fourth factor. Therefore, the number of factors was set as four (Cokluk et al., 2010). After the number of factors was set, "rotated component matrix" table was examined to determine the sub-dimensions of the items (Secer, 2013). The table indicates that the scale consists of four sub-dimensions/factors, there are no overlapping factors and the factor load of each item is higher than 0.30 . According to these results, the scale consists of 22 items, under four factors. The factors were set as confidence, relevance, attention, satisfaction.

In the confirmatory factor analysis, $\chi^{2} / \mathrm{sd}$ value was found to be $3.293, \mathrm{~A} \chi^{2} / \mathrm{sd}$ value greater than 5 indicates a discordance (Ozdamar, 2016). CFI value was calculated as 953. A CFI value greater than 0.90 is acceptable (Ozdamar, 2016). RMSEA value was found to be 071. This value being lower than 0.10 is an acceptable result (Ozdamar, 2016, p. 185). Based on these results, it can be said that the scale construct that is obtained by exploratory factor analysis is validated and acceptable in terms of fit indices.

In the confirmatory factor analysis, the regression values indicate the power of the observed variables to predict the sub-dimensions (Karagoz, 2016). Regarding the factor loads of the scale, they ranged between $0.82-0.90$ for confidence sub-dimension; $0.72-0.88$ for attention sub-dimension; $0.81-0.91$ for relevance sub-dimension; and 0.75-0.86 for satisfaction sub-dimension. Since $p<.05$ for these values, the load of items on factors is significant. In other words, it can be said that the items were appropriately assigned to the factors (Karagoz, 2016).

In addition to these results, covariance, correlation and variance values among subdimensions are also important. Since $\mathrm{p}<0.05$ for the covariance, correlation and variance values of paired sub-dimensions, it can be said that these results are statistically significant (Karagoz, 2016). According to the results, there is a strong relationship between the subdimensions. 
The Cronbach Alpha coefficients of the whole scale and its sub-dimensions were calculated. Confidence's Cronbach Alpha coefficient is .95, relevance Cronbach Alpha coefficient is .94, attention Cronbach Alpha coefficient is .93, satisfaction Cronbach Alpha coefficient is .91, scale Cronbach Alpha coefficient is .97. According to these results, both the whole scale and its dimensions have high reliability.

The high variance of the scale items will indicate that the respondents did not responded to the item in the same way (DeVellis, 2014). The variance of the items of the motivation scale for STEM fields was found to be greater than 0.703 . The mean of a scale being close to the center of the score range is a desirable feature (DeVellis, 2014). Mean items of the scale ranged from 3.09 to 3.48 . Therefore, this means close to 3 satisfy this condition.

Items on a scale should have a strong relationship with the item group outside of them (DeVellis, 2014). This relationship is expressed by the correlation coefficient and this value should be greater than 0.20 (Tavsancil, 2010). In the study, corrected item total correlation for all items of the scale was greater than 0.640 .

It was found that the scale developed in the research can measure the distinction between the upper and lower groups. As a result of the factor analyzes, item analyzes and reliability analyzes described above, it was concluded that a valid and reliable 22-item and four-factor Motivation scale for STEM fields was developed (Appendix 1).

\section{Suggestions}

Motivation scale for STEM fields developed for high school students can be used in experimental studies or descriptive studies. Validity and reliability studies can be performed by applying the scale to different education levels and it can be used in the researches.

\section{Acknowledgement}

This study was produced from the doctoral thesis of the first author, which has been presented as an oral presentation at World STEM Education Conference and the abstract has been published. 


\section{References}

Aeschlimann, B., Herzog, W., \& Makarova, E. (2016). How to foster students' motivation in mathematics and science classes and promote students' STEM career choice. A study in Swiss high schools. International Journal of Educational Research, 79, 31-41.

Bahar, A., \& Adiguzel, T. (2016). Analysis of factors influencing interest in STEM career: Comparison between American and Turkish high school students with high ability. Journal of STEM Education: Innovations and Research, 17(3), 64-69.

Baypinar, K., \& Tarim, K. (2019). The development of mathematical literacy self-efficacy scale for middle school: a reliability and validity study. Çukurova Üniversitesi Eğitim Fakültesi Dergisi, 48(1), 878-909.

BCG (2019). https://www.bcg.com/capabilities/operations/embracing-industry-4.0rediscovering-growth.aspx

Buyruk, B., \& Korkmaz, Ö. (2016). FeTeMM farkındalık ölçeği (FFÖ): Geçerlik ve güvenirlik çalışması [STEM awareness scale (SAS): Validity and reliability study]. Journal of Turkish Science Education, 11(1), 3-23.

Christensen, R., Knezek, G., \& Tyler-Wood, T. (2015). A retrospective analysis of STEM career interest among mathematics and science academy students. International Journal of Learning, Teaching and Educational Research, 10(1).

Cetin Dindar, A. \& Geban, O. (2015). Fen bilimleri motivasyon ölçeğinin Türkçe'ye ve Kimya'ya uyarlanması: geçerlilik çalışması [Adaptation of the science motivation scale into Turkish and chemistry: Analysis of validity]. Pegem Ĕgitim ve Öğretim Dergisi, 5(1), 15-34.

Cevik, M. (2017). Ortaöğretim öğretmenlerine yönelik FeTeMM Farkındalık Ölçeği (FFÖ) geliştirme çalışması [A study of STEM Awareness Scale development for high school teachers]. International Journal of Human Sciences, 14(3), 2436-2452.

Cokluk, Ö., Sekercioglu, G. \& Buyukozturk, S. (2010). Sosyal bilimler için çok değişkenli istatistik: SPSS ve LISREL uygulamalarn [Multivariate statistics for social sciences: SPSS and LISREL applications]. Ankara: Pegem Akademi.

Derin, G., Aydin, E., \& Kirkic, K. A. (2017). STEM (Fen-Teknoloji-Mühendislik-Matematik) eğitimi tutum ölçeği [A scale on the attitudes towards STEM education]. El-Cezeri Journal of Science and Engineering, 4(3), 547-559.

DeVellis (2014). Ölçek geliştirme ilkeleri. T. Totan (Çev. Ed.), Ölçek Geliştirme (A. S. Sağkal, Çev.) [Scale development] içinde (s.73-114). Ankara: Nobel.

Guzey, S. S., Harwell, M., \& Moore, T. (2014). Development of an instrument to assess attitudes toward science, technology, engineering, and mathematics (STEM). School Science and Mathematics, 114(6), 271-279.

Haciomeroglu, G., \& Bulut, A. S. (2016). Entegre FeTeMM öğretimi yönelim ölçeği Türkçe formunun geçerlik ve güvenirlik çalışması [Integrative STEM teaching intention questionnaire: A validity and reliability study of the Turkish form]. Eğitimde Kuram ve Uygulama, 12(3), 654-669. 
Ilhan, M., \& Cetin, B. (2013). Ortaokul öğrencilerinin matematik odaklı akademik risk alma davranışları: bir ölçek geliştirme çalışması [Secondary school students' academic risk taking behaviors: A scale development study]. E-uluslararası Ĕ̆itim Araştırmaları Dergisi, 4(2), 1-28.

Jayarajah, K., Saat, R. M. \& Rauf, R. A. A. (2014). A review of science, technology, engineering \& mathematics (STEM) education research from 1999-2013: A malaysian perspective. Eurasia Journal of Mathematics, Science \& Technology Education, 10(3).

Karagoz, Y. (2016). SPSS 23 ve AMOS 23 uygulamal istatistiksel analizler [SPSS 23 and AMOS 23 applied statistical analysis]. Ankara: Nobel.

Kearney, C. (2016). Efforts to increase students' interest in pursuing mathematics, science and technology studies and careers. National measures taken by 30 countries - 2015 Report, European Schoolnet, Brussels.

Keller, J. M. (2010). Motivational design for learning and performance: The ARCS model approach. New York, USA: Springer.

Kier, M. W., Blanchard, M. R., Osborne, J. W., \& Albert, J. L. (2013). The development of the STEM career interest survey (STEM-CIS). Research in Science Education, 1-21.

Koyunlu Unlu, Z., Dokme, I., \& Unlu, V. (2016). Adaptation of the science, technology, engineering, and mathematics career interest survey (STEM-CIS) into Turkish. Eurasian Journal of Educational Research, 63, 21-36.

Kuscu, P. C. (2018). Yeni bir dönem: “Sanayi 4.0" [A new era: “Industry 4.0"]. İ̧̧KUR Meslek Seçimine Destek, 5. Korza Yayıncılık: Ankara.

Milner, D. I., Horan, J. J., \& Tracey, T. J. (2014). Development and evaluation of STEM interest and self-efficacy tests. Journal of Career Assessment, 22(4), 642-653.

Mizell, S., \& Brown, S. (2016). The current status of STEM education research 20132015. Journal of STEM Education: Innovations and Research, 17(4), 52.

Oh, Y. J., Jia, Y., Lorentson, M., \& LaBanca, F. (2013). Development of the educational and career interest scale in science, technology, and mathematics for high school students. Journal of Science Education and Technology, 22(5), 780-790.

Ozdamar, K. (2016). Eğitim, sağlık ve davranış bilimlerinde ölçek ve test geliştirmel yapısal eşitlik modellemesi [Scale and test development / structural equation modeling in education, health and behavioral sciences]. Eskişehir: Nisan Kitabevi.

Robnett, R. D., \& Leaper, C. (2012). Friendship groups, personal motivation, and gender in relation to high school students' STEM career interest. Journal of Research on Adolescence, 23(4), 652-664.

Secer, İ. (2013). SPSS ve LISREL ile pratik veri analizi: Analiz ve raporlaştırma [Practical data analysis with SPSS and LISREL: Analysis and reporting]. Ankara: Anı Yayınc1lık.

Seker, G., \& Kaya, A. (2018). Lise öğrencilerinin meslek seçiminde aile desteği: Bir ölçek geliştirme çalışması [Family Support in High School Students' Choice of Vocation: A Scale Development Study]. Türk Psikolojik Danışma ve Rehberlik Dergisi, 8(49), 157-171. 
Tahiroglu, M., \& Cakır, S. (2014). İlkokul 4. sınıflara yönelik matematik motivasyon ölçeğinin geliştirilmesi [Development of mathematics motivation scale related to elementary education 4th grade]. Ahi Evran Üniversitesi Kırşehir Eğitim Fakültesi Dergisi, 15(3), 2948.

Tavsancil, E. (2010). Tutumların ölçülmesi ve SPSS ile veri analizi [Measurement of attitudes and data analysis with SPSS] (4. edition). Ankara: Nobel Yayın Dağıtım.

Tyler-Wood, T., Knezek, G., \& Christensen, R. (2010). Instruments for assessing interest in STEM content and careers. Journal of Technology and Teacher Education, 18(2), 345-368.

UKCES (2015). Reviewing the requirement for high level STEM skills.

Wang, X. (2013). Why students choose STEM majors: Motivation, high school learning, and postsecondary context of support. American Educational Research Journal, 50(5), 10811121.

Yildirim, B. \& Selvi, M. (2015). STEM tutum ölçeğinin Türkçeye uyarlanması [Adaptation of STEM attitude scale to Turkish]. Turkish Studies - International Periodical for the Languages, Literature and History of Turkish 10(3), 1107-1120.

Yilmaz, H., Yigit Koyunkaya, M., Guler, F., \& Guzey, S. (2017). Fen, Teknoloji, Mühendislik, Matematik (STEM) eğitimi tutum ölçeğinin Türkçe' ye uyarlanması [Turkish adaptation of the attitudes toward Science, Technology, Engineering, and Mathematics (STEM) education scale]. Kastamonu Eğitim Dergisi, 25(5), 1787-1800. 


\section{Appendix 1. Motivation scale for STEM fields}

Her bir madde için boş bırakılan yere sırasıyla fen, teknoloji, mühendislik ve matematik kelimelerini yazarak, ilgili sütuna ayrı ayrı puan veriniz.

Puan verirken sizin için en uygun olan cümlelere 5 puan, en az uygun olan cümlelere 1 puan olacak şekilde 1-5 aralığında bir puan veriniz.

\begin{tabular}{|c|c|c|c|c|c|c|c|}
\hline No & Maddeler & $\begin{array}{l}\text { Alt } \\
\text { Boyutlar }\end{array}$ & $\begin{array}{l}\text { Fen } \\
\text { (Sütun 1) }\end{array}$ & $\begin{array}{l}\text { Teknoloji } \\
\text { (Sütun 2) }\end{array}$ & $\begin{array}{l}\text { Mühendislik } \\
\text { (Sütun 3) }\end{array}$ & $\begin{array}{l}\text { Matematik } \\
\text { (Sütun 4) }\end{array}$ & $\begin{array}{l}\text { Maddenin } \\
\text { Toplam } \\
\text { Puanı } \\
\text { (Sütun 1+ } \\
\text { Sütun 2+ } \\
\text { Sütun 3+ } \\
\text { Sütun 4) } \\
\text { /4 }\end{array}$ \\
\hline 1 & ... alanında ilginç olaylar vardır. & & & & & & \\
\hline 2 & ... alanı benim için dikkat çekicidir. & & & & & & \\
\hline 3 & ... alanında merakımı uyandıran şeyler & & & & & & \\
\hline $\begin{array}{l}4 \\
5 \\
6\end{array}$ & $\begin{array}{l}\text { var. } \\
\text {...alanında dikkatimi çeken şeyler var. } \\
\text {... alanındaki bilgiler bana ilginç gelir. } \\
\text {... alanındaki yenilikler dikkatimi } \\
\text { çeker. }\end{array}$ & Dikkat & & & & & \\
\hline 7 & $\begin{array}{l}\text { Üniversitede ... alanındaki bölümler } \\
\text { beklentilerim ile ilişkilidir. }\end{array}$ & & & & & & \\
\hline 8 & $\begin{array}{l}\text { Üniversitede ... alanındaki bölümler } \\
\text { hedeflerim ile ilişkilidir. }\end{array}$ & & & & & & \\
\hline 9 & $\begin{array}{l}\text {... alanındaki meslekler gelecek } \\
\text { planlarımla ilişkilidir. }\end{array}$ & İlişki & & & & & \\
\hline 10 & $\begin{array}{l}\text {.. alanındaki meslekler hayattan } \\
\text { beklentilerimle bağlantılldır. }\end{array}$ & & & & & & \\
\hline 11 & $\begin{array}{l}\text { Üniversitedeki ... alanı gelecek } \\
\text { planlarımla ilişkilidir. }\end{array}$ & & & & & & \\
\hline 12 & $\begin{array}{l}\text {... alanındaki mesleklerde başarılı } \\
\text { olacağıma inanyorum. }\end{array}$ & & & & & & \\
\hline 13 & $\begin{array}{l}\text {... alanındaki konuları anlayacağıma } \\
\text { eminim. }\end{array}$ & & & & & & \\
\hline 14 & Üniversitedeki ... alanının benim için & & & & & & \\
\hline 15 & $\begin{array}{l}\text { kolay olacağına inanıyorum. } \\
\text { ‥ alanındaki bilgileri } \\
\text { öğrenebileceğime eminim. }\end{array}$ & Güven & & & & & \\
\hline 16 & $\begin{array}{l}\text {... alanındaki konularda kendime } \\
\text { güvenirim. }\end{array}$ & & & & & & \\
\hline 17 & $\begin{array}{l}\text { Üniversitede ... alanında başarılı } \\
\text { olacağıma inanyorum. }\end{array}$ & & & & & & \\
\hline 18 & $\begin{array}{l}\text { Üniversitede ... alanını kazanırsam } \\
\text { mutlu olurum. }\end{array}$ & & & & & & \\
\hline 19 & $\begin{array}{l}\text {... alanındaki konuları anlamak bana } \\
\text { başarı duygusu verir. }\end{array}$ & & & & & & \\
\hline 20 & $\begin{array}{l}\text {... alanındaki yeni bilgileri } \\
\text { öğrenmekten zevk alırım. }\end{array}$ & Doyum & & & & & \\
\hline 21 & $\begin{array}{l}\text { Üniversitede... alanını kazanırsam } \\
\text { kendimi başarılı hissederim. }\end{array}$ & & & & & & \\
\hline 22 & $\begin{array}{l}\text {... alanında bir meslek sahibi olursam } \\
\text { kendimle gurur duyarım. }\end{array}$ & & & & & & \\
\hline
\end{tabular}

